\title{
The Effect of Organizational Culture on Lecturer Performance at State Islamic Religious College (PTKIN) in Aceh Province
}

\author{
Yusaini \\ Institute of State Islamic Religion \\ Langsa, Aceh \\ Parlindungan Pangaribuan, \\ State University of Medan \\ Harun Sitompul \\ State University of Medan
}

\begin{abstract}
The lecturers problem has been criticized by many people including academics, practitioners, and government. They questioned a number of lecturers performance with various problem in the university. The formulation of the problem in this research is there anyeffect of organizational culture on the performance of lecturer of Islamic Higher Religious College (PTKIN) in Aceh Province. The purpose of this study is to determine the influence of Organizational Culture on Performance lecturer PTKIN in Aceh Province. The population of this research are all lecturers at 5 (five) PTKIN in Aceh Province namely; IAIN Langsa, IAIN Malikussaleh Lhokseumawe, STAIN Gajah Puteh Takengon, UIN Ar-raniry Banda Aceh and STAIN ChikDirundengMeulaboh, which amounted to 727 people. The
\end{abstract}

\section{INTRODUCTION}

The lecturers performance of the State College of Islamic Religious (PTKIN) in Aceh province is a variable that needs to be analyzed in order to improve lecturers' performance. Lecturers' performance is an urgent reason to be studied by hoping that it will have a significant contribution in achieving the goals of Islamic universities in Aceh. Lecturer's performance is the ability that can be shown in completing the work program at a certain time to achieve the institution's goal. Thus, the lecturers' performance can be analyzed in term of good and bad are from their achievement. According to Ari Cahyono, Performance is the result of work achieved by a person in performing the tasks that are his responsibility within a certain time and according to the criteria of measurement through indicators: 1) quality; 2) quantity; 3) timeliness.

Robbins, S.P., dan Mary Coulter (2007:564), explain that: “... performance is all of these. It's the end result of an activity and whether that activity is hours of intense practice before a consert or race or whether it's carrying out job responsibility as efficiently and effectively as possible, performance is what results from that activity". Thus technique of determining the sample in this study was taken by Proportional Randoms Sampling of the Solvin formula, where with this technique the number of samples used counted 258 people. The research instrument used is a questionnaire with Likert scale.Research data is processed and analyzed by simple regression analysis. This analysis begins by testing the requirements analysis including normality test, linearity test and regression significance. The results of this study indicate that organizational culture directly determines the performance of the lecturer of PTKIN in Aceh Province is $31.9 \%$, while the rest is influenced by other variables outside the variables in this study.

\section{Keywords: Organizational Culture, and Lecturer Performance}

performance must be analyzed from the result undertaken within a certain time with the consideration of effective and efficient Kinerja itu harus dilihat dari hasil yang dikerjakan dalam jangka waktu tertentu dengan pertimbangan efektif dan efisien. Moreover, Colquitt, et. Al., (2009:37), say that: "job performance is formally defined as the value of the set of employee behaviors that contribute, either positively or negatively, to organizational goal accomplishment".

There are different models according to expert in understanding the influence of each variable that affects the lecturers' performance, for instance; model developed by Qolquitt that organizational performance and commitment are outcomes variable which is directly influenced by work satisfaction. While leadership and organizational culture have no direct effect for the performance. While John W. Newstroom shows a model that outcomes variable is the performance and job satisfaction which have same variable. Whereas Qolquitt models, job satisfaction is a variable that affects performance. Furthermore, the results of research $\mathrm{Li}$ Chuan Chu, Ph.D and Chun-Che Lai found that organizational commitment is a variable that affects employee performance; it is not as a outcomes variable. From these three experts describe the contradiction models for between variables, both the position of exogenous and endogenous variables. They 
persist on the findings of their respective theories. Based on the background and problem identification, this study aims to determine whether Organizational Culture is directly affect toward the lecturers' performance.

\section{THEORETICAL FRAMEWORK}

Performance is a variable that is often to be a target of researchers to be studied and analyzed in various institutions, both government and private agencies. So, many people want to know clearly the meaning of employee performance. Epistemologically that the word performance comes from the word "to perform" which has several meanings, namely: (1) doing; (2) fulfill or run something; (3) carrying out a responsibility; and (4) doing something what one would expect (Marwan, 2017:34).

Performance is the result obtained by an organization, whether the organization is profit oriented and nonprofit oriented generated over a period of time. Performance is the work result that has strong relationship with the strategic objectives of organization, customer satisfaction, and provides economic contribution. Performance can be said as a description of the achievement level in implementation of an activity/program/policy in realizing the goals, objectives, mission and vision of an organization/institution stated in the formulation of an organization's strategic scheme (Fahmi, I., 2014:127).

Gibson (in Eri Murianto, 2011) there are three factors that affect performance, they are:

1. Organizational factors; consisting of resource variables, leadership behaviors, rewards, structure, and job design.

2. Individual factors; consisting of the ability, personal and demographic background. Ability and skill variables are the main factors affecting work behavior and individual performance. While demographic variable affects indirectly.

3. Psychological factors; consisting of perception, attitude, personality, learner and motivation variables. These variables are heavily influenced by family, social level, previous work experience and demographic variable.

Kreitner, R. and Angelo Kinicki (2014), say that performance will not develop without support systems, such as those with the necessary ability, skills, and knowledge to be recruited. Further Wibowo cited from Armstrong and Baron (1998:16) that factors affect performance as follows:

1. Personal Fakctors, indicated by the level of skills, competencies, motivation, and individual commitment.

2. Leadership factors, determined by the quality of encouragement, guidance, and support given by managers and team leader.

3. Team Factors, indicated by the support qualities provided by co-workers.

4. System Factors, indicated by the existence of work systems and facilities provided by the organization.

5. Contextual/Situational Factors, indicated by high levels of pressure and changes in internal and external environment.
According to Robbins and Judge (in Indah, 2015:179), mentioned that the organizational culture is as a meaning system embraced by the organization members that differentiate the organization from other organizations. It shows that an organizational culture is formed based on norms and foundations that have been recognized together all the time that has been passed in working on an organization.

Robbins, S.P., and Mary Coulter (2010:63), provide a definition of organizational culture as values, principles, traditions and ways of working shared by members of the organization and affect the way they act. Most of these shared organizations, values and practices have grown rapidly with the times and really affect how an organization is run.

The organizational culture that is designed and created in an organization depends much on the wishes of the manager or a leader. Leaders can create desired culture or work environment within a certain limit of time. So, organizational culture is an environment that can be created by the leadership for his employees and customers. Usually, the organizational culture that the leader wants is to promote the quality and to appreciate the comfort of each other. ( Robbins, S.P., dan Mary Coulter, 2010:63).

Kreitner, R., and Angelo Kinicki (2014:62), explain that organizational culture is an assumption device that is shared and received implicitly and held by a group that determines how things is felt, thought and reacted to a diverse environment This is in line with what Yukl, G. (2001:334) defines that "organizational culture is a shared assumption and belief about the world and their place in it, the nature of time and space, human nature, and human relationships."

Thus, the main function of organizational culture is to help to understand the environment and determine how to respond, thereby reducing anxiety, uncertainty, and confusion. So that when they get a problem, then through experience they will find solutions where the solution made as a shared assumption in previous work experience. This condition will be received and recognized the experience at the same time. Lunenburg. F.C., and Allan C. (2000:10) define that "Ornstein mendefinisikan bahwa The Culture of an organization is all the beliefs, feeling, behaviors, and symbols that are characteristic of an organization. More specifically, organizational culture is defined as shared philosophies, ideologies, beliefs, feelings, assumptions, expectations, attitudes, norms, and value"

\section{RESEARCH METHODOLOGY}

The study wanted to prove the influence of exogenous variables on four of lecturers' performance. In order to reach the goal of the study, the data were collected in the form of facts based on the phenomena due to the 5 variables without giving any treatment, and survey is research method in collecting the data.

Due to the survey as the method in collecting the data, so this study categorized into "explanatory or comfirmatory" that is research that will explain about the causal relation and 
do testing of hypothesis at once. Based on the research problem, this research was conducted at 5 (five) PTKIN in Aceh province. Those 5 PTKIN are: IAIN Langsa, IAIN Malikussaleh Lhokseumawe, STAIN Gajah Puteh Takengon, UIN Ar-raniry Banda Aceh, dan STAIN Chik Dirundeng Meulaboh and the research was conducted since june 1, 2016 up to June 1, 2017. The population of the research was the permanent and non-permanent of PTKIN lectures in Aceh province that are conducted their task at their own University amounting at 727 lectures. Due to the amount of lectures at each university in Aceh province, so the population of the research is 727 . By setting up the population it is expected to be population that will generalize the conclusion of the result. Sampling for each stratum at four PTKIN can be presented in the table 1 below:

Table 1. Number of samples base on each PTKIN.

\begin{tabular}{|c|l|c|}
\hline No. & \multicolumn{1}{|c|}{ Nama PTKIN } & Sampel \\
\hline 1. & UIN Ar-raniry Banda Aceh & 173 \\
\hline 2. & IAIN Malikussaleh Lhokseumawe & 30 \\
\hline 3. & IAIN Zawiyah Cot Kala Langsa & 30 \\
\hline 4. & $\begin{array}{l}\text { STAIN Teungku Dirundeng } \\
\text { Meulaboh }\end{array}$ & 2 \\
\hline 5. & STAIN Gaja Puteh Takengon & 23 \\
\hline & Total & 258 \\
\hline
\end{tabular}

Source: Primer Data, 2016.

\section{Research Instrumen}

The instruments preparation for the two variables (organizational culture, and lecturer performance) are conducted by arranging the instrument grid in which the indicator will be determined, the questionnaire number, form and the number of items. Then the instruments preparation for both variables can be described as in each of the following instrument explanations.

a. Instrumen organizational culture

Table: 2. Grid of Organizational culture variable (X1)

\begin{tabular}{|c|l|c|c|}
\hline No. & \multicolumn{1}{|c|}{ Indikator } & $\begin{array}{c}\text { Questionnaire } \\
\text { item }\end{array}$ & $\begin{array}{c}\text { Total } \\
\text { items }\end{array}$ \\
\hline 1. & Inovasi and risk taking & $1,2,3,4,5$ & 5 \\
\hline 2. & Attention on the detail & $6,7,8,9,10$ & 5 \\
\hline 3. & $\begin{array}{l}\text { Result orientation (Work } \\
\text { opportunity) }\end{array}$ & $11,2,13,14,15$ & 5 \\
\hline 4. & $\begin{array}{l}\text { People Orientation } \\
\text { (Individu) }\end{array}$ & $16,17,18,19,20$ & 5 \\
\hline 5. & Tim Orientation & $21,22,23,24,25$ & 5 \\
\hline 6. & Aggressiveness & $26,27,28,29,30$ & 5 \\
\hline 7. & Stability & $31,32,33,34,35$ & 5 \\
\hline & Number of questionnaire & 35 \\
\hline
\end{tabular}

b. Instrumen Lecturer performance

Table 3. Grid of Lecturer performance $\left(\mathrm{X}_{2}\right)$

\begin{tabular}{|c|l|c|c|}
\hline No. & Indikator & Number of Questionnaire & $\begin{array}{c}\text { Total } \\
\text { item }\end{array}$ \\
\hline 1. & Teaching & $\begin{array}{c}115,116,117,118,119,120, \\
121,122,123\end{array}$ & 9 \\
\hline 2. & Researcher & $124,125,126,127,128,129$ & 6 \\
\hline 3. & $\begin{array}{l}\text { Communit } \\
\text { y service }\end{array}$ & $130,131,132,133,134$ & 5 \\
\hline 4. & $\begin{array}{l}\text { Students } \\
\text { conselor }\end{array}$ & $135,136,137,138,139$ & 4 \\
\hline 5. & leader & $140,141,142,143,144$ & 5 \\
\hline 6. & Inovator & $145,146,147,148,149$ & 5 \\
\hline 7. & Motivator & $150,151,152,153,154$ & 5 \\
\hline \multicolumn{3}{|c|}{ Total number of questionnaire } & 40 \\
\hline
\end{tabular}

In order that these two instruments to be valid and reliable, so all instruments are tested after having permission to collect data both from pascasarjana unimed medan and from the five PTKIN in Aceh province. According to Siregar, S. (2013:77), result analysis of the tested instruments can be counted by using Product Moment formulas as the following:

$$
r_{x y}=\frac{n\left(\sum x_{i} y_{i}\right)-\left(\sum x_{i}\right)\left(y_{i}\right)}{\sqrt{\left[n \cdot \sum \cdot X_{i}^{2}-\left(\sum X_{i}\right)^{2}\right] \cdot\left[n \cdot \sum \cdot Y_{i}^{2}-\left(\sum Y_{i}\right)^{2}\right]}}
$$

In which:

$$
\begin{aligned}
r_{x y} & =\text { Koefesien of relation between } \mathrm{X} \text { and } \mathrm{Y} \\
\mathrm{X} & =\text { Score of each item } \\
\mathrm{y} & =\text { total score of each item } \\
\mathrm{n} & =\text { the amount of respondent }
\end{aligned}
$$

Furthermore, each question item in the questionnaire of the five instruments will also be tested for reliability as a reliable and consistent question point to the data collected. Reliability questionnaire was analyzed by Alpha Cronbach technique by using the following formula:

$$
\begin{aligned}
& r_{k}=\left(\frac{k}{k-1}\right)\left(1-\frac{\sum S t^{2}}{S t^{2}}\right) \\
& \text { Remark: }
\end{aligned}
$$

$$
\begin{aligned}
r_{k} & =\text { Instrument reliabily } \\
\mathrm{k} & =\text { number of item } \\
\sum S t^{2} & =\text { number of valid varians } \\
S t^{2} & =\text { total varians }
\end{aligned}
$$

The invalid items are revised and tested again, and the questionnaire used in this research was 36 items. Meanwhile, the test results of the questionnaire reliability of each variable in this study are summarized in Table 4. below. 
Table 4:.Summary of Research Instrument for Reliable Test Result

\begin{tabular}{|c|c|c|}
\hline No. & $\begin{array}{c}\text { Instrumen } \\
\text { Variabel }\end{array}$ & Koefisien Alpha \\
\hline 1. & Organizational Culture $\left(\mathrm{X}_{1}\right)$ & 0,900 \\
\hline 5. & Lecturer performance $\left(\mathrm{X}_{2}\right)$ & 0,969 \\
\hline
\end{tabular}

Based on Table 4, it can be seen that the organizational culture variable obtained the reliability coefficient of 0.900 . Furthermore, by referring to Kaplan's opinion in EkoPutroWidoyoko stating an instrument is said to be reliable if it has an Alpha coefficient value of at least 0.70. Thus the questionnaire variable for Organizational culture is reliable. Lecturer Performance Variables obtained reliability coefficient of 0.969. Referring to Widyoko's opinion above, the overall value of Alpha coefficient is above 0.70 , thus the questionnaire for all of these research variables is reliable as a whole.

\section{Technique of data collection;}

Data collection techniques carried out in this research is a survey technique. It was conducted by distributing questionnaires to lecturers who have been specified as a sample, that a number of lecturers who have been set on the determination of the sample, they are; lecturers of UIN Arraniry Banda Aceh, IAIN Langsa, IAIN Malikussaleh Lhokseumawe, STAIN Chik Dirundeng Meulaboh, STAIN Gajah Puteh Takengon. The technique of distributing questionnaires in this study is used to collect primary data, ie data obtained directly from respondents or lecturers who have been specified as a sample. By distributing questionnaires, it will be obtained data/information about assessment variables that are organizational culture $\left(\mathrm{X}_{1}\right)$, and lecturer performance $\left(\mathrm{X}_{2}\right)$.

\section{Data Analysis}

After the data collection is performed, the next step is to analyze the data. Data will be analyzed descriptively, tested statistical analysis requirements, through path analysis. Basically, the complete research is consisting of five variables. While in this article are only two variables discussed, namely organizational culture and lecturer performance.

\section{RESULT}

From the examination that has been conducted to the entire data, all of them meet the requirements to be analyzed. Briefly it can be stated that the description of the data reveals information about the total score, the highest score, the lowest score, the average, the range, the standard deviation. The following table 4.1 presented the basic statistical calculation figures of the five data variables.

\section{Data of Organizational Culture}

Due to calculation and description of the data, the organizational culture variable obtained the lowest score is 67 and the highest is 125 . While the average value of 102.58 , standard deviation 12.65, median 103, and mode 101. This data distribution shows that the average score, medians and modes are not much different, indicating that the distribution of data tends to be normally distributed. In accordance with the basic statistical calculation results, the data are classified using the Starges rule into 9 (nine) class intervals. In order to have detail information of score distribution for the variable of organizational culture, it is shown in the Table 5 as the following:

Table 5: Distribusi Frekuensi Skor Budaya organisasi

\begin{tabular}{|c|c|c|c|}
\hline No & Interval Class & f Absolut & F.Relatif (\%) \\
\hline 1 & $67-73$ & 8 & $3,1 \%$ \\
\hline 2 & $74-80$ & 11 & $4,3 \%$ \\
\hline 3 & $81-87$ & 15 & $5,8 \%$ \\
\hline 4 & $88-94$ & 22 & $8,5 \%$ \\
\hline 5 & $95-101$ & 59 & $22,9 \%$ \\
\hline 6 & $102-108$ & 52 & $20,2 \%$ \\
\hline 7 & $109-115$ & 45 & $17,4 \%$ \\
\hline 8 & $116-121$ & 34 & $13,2 \%$ \\
\hline 9 & $122-128$ & 12 & $4,7 \%$ \\
\hline & Total & 258 & $100 \%$ \\
\hline
\end{tabular}

The above table shows the distribution of organizational culture score as much as 115 people $(44,6 \%)$ is below class average, 52 people $(20,2 \%)$ are in class average and 91 people $(33.3 \%)$ above average. Based on the data above, the organizational culture is generally below average.

\section{Data of lecturer performance}

In accordance with the basic statistical calculation results, the data are classified using the Sturges rule into nine class intervals. In order to have clear picture about the score for the variable of lecturer performance, it can be viewed on table 6 below.

Table 6: frequency distribution score of lecturer performance variable

\begin{tabular}{|c|c|c|c|}
\hline No & Interval Class & f Absolut & F.Relatif (\%) \\
\hline 1 & $91-97$ & 6 & $2,3 \%$ \\
\hline 2 & $98-104$ & 19 & $7,4 \%$ \\
\hline 3 & $105-111$ & 19 & $7,4 \%$ \\
\hline 4 & $112-118$ & 47 & $18,2 \%$ \\
\hline 5 & $119-125$ & 45 & $17,4 \%$ \\
\hline 6 & $126-132$ & 47 & $18,2 \%$ \\
\hline 7 & $133-139$ & 43 & $16,7 \%$ \\
\hline 8 & $140-146$ & 25 & $9,7 \%$ \\
\hline 9 & $147-153$ & 7 & $2,7 \%$ \\
\hline & Jumlah & 258 & $100 \%$ \\
\hline
\end{tabular}


Table 6 shows the distribution that the lecturer's performance score of 91 people $(35.3 \%)$ was below the interval class average, 45 people $(17.4 \%)$ were in the interval class average and as many as 122 people $(47.3 \%)$ above average. Based on the above data, the lecturer's performance is generally above average or categorized well.

\section{Inter-Correlation Test of Variables $\mathrm{X}_{1}$ dan $\mathrm{X}_{2}$}

From the calculation of correlation test variables $\mathrm{X}_{1}$ and $\mathrm{X}_{2}$ it is obtained $\mathrm{r}_{\text {hitung }}=0,623$ meanwhile $\mathrm{r}_{\text {tabel }}$ with $\mathrm{N}=258$ and level significant $5 \%$ of 0,122 . Thus $r_{\mathrm{x}_{1} \mathrm{x}_{\mathrm{s}}}>\mathrm{r}_{\text {tabel }}(0,623>0,138)$. Furthermore, the significance test of correlation by using ttest.. in which $\mathrm{r}_{\text {hitung }}=0,623$ Obtained $\mathrm{t}_{\text {hitung }}=10,032$. From the distribution list of $\mathrm{t}$ with $\mathrm{dk}=256$ and $5 \%$ significant level obtained $t_{\text {tabel }}=1,658$. Thus $r_{\text {hitung }}>r_{\text {tabel }}(0,623>0,138)$, then it can be said there is a significant correlation between organizational culture and lecturer's performance. From the distribution list $\mathrm{t}$ with $\mathrm{dk}=256$ and $5 \%$ significance level obtained $t_{\text {tabel }}=1,658$. Thus it turns out that $t_{\text {hitung }}>t_{\text {tabel }}$ $(10,032>1,658)$ so it can be concluded that there is a correlation between organizational culture variable and lecturer performance. From the calculation results can be concluded that between the organizational culture and lecturer's performance there is a significant correlation.

$$
\begin{array}{ll}
\text { Hypotesis proposed is: } & \\
\mathrm{H}_{0}: \rho_{51}=0: & \begin{array}{l}
\text { Organizational culture }\left(X_{1}\right) \text { tidak has no } \\
\text { effect on lecturer's performance }\left(X_{2}\right) .
\end{array} \\
\mathrm{H}_{0}: \rho_{51} \neq 0: & \begin{array}{l}
\text { Organizational culture }\left(X_{1}\right) \text { affects the } \\
\text { performance of lecturers }\left(X_{2}\right) .
\end{array}
\end{array}
$$

Form Table 4.25 above, it is obtained path coefficient between $\mathrm{X}_{1}$ to $\mathrm{X}_{5} \rho_{51}=0,565$ dan price $\mathrm{t}_{\text {hitung }}=10,946$. For $\mathrm{N}=258$ at $5 \%$ significant level obtained $t_{\text {tabel }}=1,650$. The result shows $t_{\text {hitung }}>t_{\text {tabel }}(10,946>1,650)$. Thus $\mathrm{Ho}$ is rejected and $\mathrm{Ha}$ accepted, so it can be concluded that organizational culture directly affects the lecturers' performance

\section{DISCUSSION}

Previous tests results showed that the organizational culture variable; high category is $5.05 \%$, medium category is $79.84 \%$, low category is $15.12 \%$ and while the less category does not exist. Thus it can be concluded that the organizational culture in this study tend to be medium and it is proven by $79.84 \%$ of respondents included in the medium category. While for the lecturer performance variable the high category is 5,04 medium is category $81.78 \%$, is low category $13.18 \%$ and while less category does not exist. Thus it can be concluded that the lecturers performance in this study tend to be shortage.

Robbins, S.P. (2006:721) Robbins states that organizational culture is a system of shared values that will be used as a guide by its members that will differentiate an organization with other organizations. Organizational culture is related to how the lecturer understands the cultural characteristics in the organization where the lecturer works, and is not related to whether the lecturer likes the characteristics of the organizational culture or not. The organizational culture of a meaning shared system, hoping that lecturers with different backgrounds or at different levels within the organization will understand the organizational culture in the same sense.

Obgor (Sopiah, 2008:181) states that "organizational culture that provides a sense of comfort in work and high confidence will encourage increased work behavior through the cohesiveness of individuals and the commitment of the citizens of the organization to do everything that is best for the interests of the organization". Robbins also confirmed several important factors that give more work satisfaction, first is a job that provides opportunities to use skills, and feedback on how well they work, the next factor is how the employees working conditions, both in terms of personal convenience and ease to do the work, these things closely related to rules and standards determined by the company, while the rules and standards are formed from the organizational culture within the company itself

\section{CONCLUSION}

According to data analysis and research problems that have been formulated, the conclusion can be made that organizational culture has a direct effect on the lecturers' performance of PTKIN in Aceh province. The effort to increase lecturer performance can be done by improving a good college culture.

\section{REFERENCES}

[1] Cahyono, A. Analisa Pengaruh Kepemimpinan, Motivasi Dan Budaya Organisasi Terhadap Kinerja Dosen Dan Karyawan Di Universitas Pawyatan Daha Kediri, Jurnal Ilmu Manajemen, Revitalisasi, 2012, 1 (1), pp. 283-298.

[2] Sari, A.P. dan Komang Ardana. Peran Mediasi Kepuasan Kerja Pada Pengaruh Kompensasi Terhadap Kinerja Pekerja Kontrak, E-Jurnal Manajemen Unud, 2016, 5, (1), pp. 470-499.

[3] Colquitt, J.A., Lipine, Michael J. Wesson. Organization Behavior: Improving Performance and Commitment in the Workplace. New York:The McGraw-Hill Com., Inc., 2009 , pp. 37.

[4] Kreitner, R. dan Angelo Kinicki. Perilaku Organisasi (Organizational Behavior). Edisi 9, Jakarta: Salemba Empat, 2014, pp. 62.

[5] Dewi, K. dan Herlen, Jumiati Sasmita. Pengaruh Budaya Organisasi dan Pengawasan terhadap Kinerja Melalui Komitmen Karyawan Frontliner PT Bank Riau Kepri. Jurnal Tepak Manajemen Bisnis, 2015, 7, (2), pp. 179191.

[6] Lunenburg, F.C, dan Allan C. Ornstein. Educational Administration, Conceps and Practices, Third Editions. USA: Wadsworth Thomson Learning, 2000, pp. 60. 
[7] Marwan. Pengaruh Budaya Organisasi, Perilaku Kepemimpinan, Motivasi Berprestasi, Melalui Kepuasan Kerja Terhadap Kinerja Dosen Perguruan Tinggi Swasta Di Provinsi Aceh.. Disertasi. Prigram Pascasarjana Universitas Negeri Medan, 2015, pp. 34.

[8] Riduwan dan Engkos Achmad Kuncoro. Skala Pengukuran Variabel-variabel Penelitian. Bandung: Alfabeta. 2009, pp. 12.

[9] Riduwan dan Engkos Achmad Kuncoro. Cara Menggunakan dan memakai Path Analysis (Analisis Jalur), Bandung: Alfabeta, 2012.

[10] Triningsih, S. Independensi Auditor dan Komitmen Organisasi Sebagai Mediasi Pengaruh Pemahaman Good Governance, Gaya Kepemimpinan dan Budaya Organiasi Terhadap Kinerja Auditor, Makalah Disampaikan Pada Acara Simposium Nasional X di Unhas Makasar, tanggal 26-28 Juli 2007, pp. 1-56.
[11] Robbins, S.P. dan Mary Coulter. Manajemen, Edisi kedelapan, Jilid 2, Jakarta: PT. Indeks, 2007.

[12] Robbins, S.P. Perilaku Organisasi. Alih Bahasa: Benyamin Molan, 2006, pp. 721.

[13] Robbins, S.P. dan Timothy A. Judge. Perilaku Organisasi. Edisi 12. Jakarta.Salemba Empat, 2007.

[14] Robbins, S.P. dan Mary Coulter. Manajemen, Edisi Kesepuluh, Jilid 1. Jakarta: Erlangga, 2010, pp. 63.

[15] Sopiah. Perilaku Organisasional. Yogyakarta: Andi Offset, 2008, pp. 181.

[16] Siregar, S. Statistik Parametrik untuk penelitian kuantitatif. Jakarta: PT. Bumi Aksara, 2013, pp. 77.

[17] Wibowo. Manajemen Kinerja, Edisi Keempat, Jakarta: PT RajaGrafindo Persada, 2007, pp. 11. 